Reviu Akuntansi dan Bisnis Indonesia, Vol. 3 No. 2, Hlm: 149-162, Desember 2019

Website: http://journal.umy.ac.id/index.php/rab

\title{
Pajak Kini, Pajak Tangguhan, Aset Pajak Tangguhan, Liabilitas Pajak Tangguhan Terhadap Manajemen Laba
}

\author{
Marista Winanti Sutadipraja; Sri Setia Ningsih; Mardiana * \\ Program Studi Akuntansi ITB Ahmad Dahlan Jakarta \\ I N F O A R T I K E L \\ Kata Kunci: \\ Pajak Kini, Pajak \\ Tangguhan, Aset Pajak \\ Tangguhan, Liabilitas Pajak \\ Tangguhan, Manajemen \\ Laba, discretionary accrual. \\ Jenis Artikel: \\ Penelitian Empiris \\ Correspondence: \\ nana_diana1985@yahoo.co.id \\ A B S T R A K \\ Implikasi PSAK 46 dikaitkan dengan isu manajemen laba dimana banyak \\ manajer memanfaatkan peluang tersebut untuk melakukan manajemen \\ terhadap angka laba pada perusahaannya dengan pendekatan akrual untuk \\ mendapat bonus atau penghargaan atas kinerja yang baik dengan \\ meminimalkan beban pajak penghasilan yang harus dibayarkan. Tujuan \\ penelitian ini adalah untuk menguji apakah terdapat pengaruh beban pajak \\ kini, pajak tangguhan, aset pajak tangguhan, dan liabilitas pajak tangguhan \\ terhadap tindakan manajemen laba pada perusahaan barang konsumsi \\ yang terdaftar di Bursa Efek Indonesia (BEI). Penelitian ini menggunakan \\ data sekunder dari laporan keuangan tahunan perusahaan yang terdaftar di \\ BEI selama periode tahun 2013-2017. Sampel penelitian ini adalah \\ perusahaan manufaktur sektor barang konsumsi yang terdaftar di BEI \\ dengan menggunakan metode purposive sampling. Uji hipotesis dalam \\ penelitian ini menggunakan analisis regresi linier berganda. Manajemen \\ laba di proksikan dengan discretionary accrual dengan menggunakan \\ Modified Jones Model (Dechow, 1995). Hasil penelitian menunjukkan \\ pajak kini, pajak tangguhan, dan aset pajak tangguhan berpengaruh secara \\ signifikan terhadap manajemen laba. Variabel liabilitas pajak tangguhan \\ tidak memiliki pengaruh terhadap manajemen laba.
}

(C) 2019 RAB. Published by Universitas Muhammadiyah Yogyakarta

\section{PENDAHULUAN}

Manajemen laba menjadi topik penting dalam literatur akuntansi selama lebih dari 20 tahun. Menurut Walker dalam Wang (2016) meninjau literatur tentang manajemen laba selama periode 20 tahun. Walker menemukan lebih dari 311 artikel dan 274 artikelnya diterbitkan di jurnal Amerika Utara. Walker percaya bahwa minat dalam manajemen laba sebagai topik penelitian telah meningkat sejak tahun 2005. Berbagai peneliti mendefinisikan manajemen laba dengan cara yang sedikit berbeda.

Schipper dalam Wang (2016) mendefinisikan manajemen laba sebagai intervensi yang disengaja dalam proses pelaporan keuangan eksternal, dengan maksud memperoleh beberapa keuntungan pribadi. Mulford dan Comisky dalam Wang (2016) menyatakan hal tersebut adalah manipulasi aktif dari laba terhadap target yang telah ditentukan; Walker dalam Wang (2016) menyebut manajemen laba penggunaan kebijaksanaan manajerial (dalam GAAP) atas pilihan akuntansi, pilihan pelaporan laba, dan keputusan ekonomi nyata untuk mempengaruhi bagaimana peristiwa ekonomi yang mendasarinya tercermin dalam satu atau lebih ukuran pendapatan; dan Healy dalam Wang (2016) melihatnya sebagai perubahan laporan keuangan perusahaan oleh orang 
dalam untuk menyesatkan beberapa pemangku kepentingan atau untuk mempengaruhi hasil kontrak yang bergantung pada angka dalam laporan keuangan.

Kondisi perusahaan yang tidak sehat seringkali oleh manajemen ditutupi dengan menampilkan atau melaporkan kinerja keuangannya tetap baik dengan melakukan manajemen laba. Salah satu cara perusahaan dapat mengelola pendapatan mereka adalah dengan membuat penyesuaian akrual diskresioner, yang diizinkan karena basis akrual akuntansi memerlukan perkiraan yang harus dibuat sebagai bagian dari proses akuntansi dan pelaporan keuangan.

Perusahaan di Indonesia dalam hal penyusunan laporan keuangan berpedoman pada Pernyataan Standar Akuntansi Keuangan (PSAK), sedangkan untuk kepentingan pajak berpedoman pada Peraturan Perpajakan. Adanya perbedaan antara prinsip akuntansi dengan aturan perpajakan mengharuskan manajer untuk membuat dua jenis laporan laba rugi, yaitu laporan laba rugi komersil dan laporan laba rugi fiskal. Laporan laba rugi komersil disusun berdasarkan Standar Akuntansi Keuangan, sedangkan laporan laba rugi fiskal disusun berdasarkan aturan perpajakan. Peraturan Perpajakan mengharuskan perusahaan melakukan rekonsiliasi fiskal untuk menyesuaikan perbedaan konsep pajak dengan konsep akuntansi komersial. Dalam konteks akuntansi atas pajak penghasilan, perbedaan tersebut menghasilkan dua jenis beda, yaitu beda waktu (temporary differences) dan beda tetap (permanent differences). (Amanda, 2015).

Berdasarkan PSAK No. 46, pajak kini adalah jumlah pajak penghasilan yang terutang atas laba kena pajak untuk satu periode. Beban pajak kini adalah jumlah pajak yang harus dibayar oleh wajib pajak (Suandy, 2011). Jumlah pajak kini harus dihitung sendiri oleh Wajib Pajak berdasarkan penghasilan kena pajak dikalikan dengan tarif pajak, kemudian dibayar sendiri dan dilaporkan dalam Surat Pemberitahuan (SPT) sesuai dengan peraturan perundang-undangan pajak yang berlaku. Oleh karena adanya perbedaan antara laba akuntansi dan penghasilan kena pajak merefleksikan tingkat kebijakan manajer dalam memanajemen laba menjadi lebih tinggi (Mills dalam Ettredge et al., 2008 dalam Deviana, 2012).

PSAK 46 menyatakan bahwa manajemen diberikan kebebasan menentukan pilihan kebijakan akuntansi dalam menentukan besaran pencadangan beban atau penghasilan pajak tangguhan atas adanya perbedaan standar akuntansi dengan peraturan perpajakan. Manajemen membutuhkan penilaian dan perkiraan tertentu, sehingga manajemen bersifat lebih fleksibel. Fleksibilitas manajemen dalam penyusunan laporan keuangan, diatur dalam PSAK No. 1 tentang penyajian laporan keuangan dengan pendekatan atau basis akrual (accrual basis). Implikasi PSAK No. 46 ini dikaitkan dengan isu manajemen laba (earnings management) dimana banyak manajer memanfaatkan peluang tersebut untuk melakukan manajemen terhadap angka laba pada perusahaannya dengan pendekatan akrual untuk mendapat bonus atau penghargaan atas kinerja yang baik dengan meminimalkan beban pajak penghasilan yang harus dibayarkan (Suranggane, 2007).

Salah satu contoh kasus pada PT. PLN (PERSERO) Distribusi Bali. Setelah dilakukan pemeriksaan pajak, didapatkan hasil yang berupa pajak penghasilan fiskal pada tahun 2003 sebesar Rp 616.206.533.565,- dan pada tahun 2004 sebesar Rp 120.344.177.465,-. Pajak tangguhan yang ada di PT. PLN (PERSERO) Distribusi Bali untuk Aktiva Pajak Tangguhan Tahun 2003 Rp 184.861.966.070,- dan Kewajiban Pajak Tangguhan Tahun 2003 sebesar Rp 65.002.051.320,-. Tahun 2004 Aktiva Pajak Tangguhan sebesar Rp 36.103.253.240,- kewajiban Pajak Tangguhan Tahun 2004 sebesar Rp 37.515.162.581,-.

Pada saat diadakan koreksi fiskal atas Laporan Laba Rugi Tahun 2003 ditemukan adanya selisih sebesar Rp57.366.518.774,-- lebih besar menurut fiskal daripada Laporan Keuangan Perusahaan. Pada Tahun 2004 juga ditemukan selisih yang lebih besar menurut fiskal daripada laporan Keungan Perusahaan sebesar Rp 48.766.124.690,-. Pada Laporan Keungan PT. PLN (PERSERO) (Laidan, 2004). Hal ini menunjukkan bahwa pajak tangguhan dijadikan celah oleh manajemen untuk mempengaruhi besarnya pajak penghasilan yang seharusnya dibayarkan.

Pajak tangguhan adalah salah satu isu yang dibahas pada PSAK 46 yang merupakan bagian paling sulit dipahami oleh sebagian besar praktisi pelaporan keuangan hingga saat ini. Pengakuan pajak tangguhan adalah konsekuensi dari alokasi pajak antar periode pelaporan keuangan dengan menggunakan pendekatan-pendekatan neraca. Teknik pencatatan ini pertama sekali diperkenalkan 
pada FAS 96 yang dikeluarkan pada tahun 1987 oleh FASB. Teknik pencatatan ini mengakibatkan pengakuan aktiva dan kewajiban pajak tangguhan. DSAK kemudian mengadopsi teknik tersebut pada tahun 1998 atau pada saat dikeluarkannya PSAK 46 (Purba, 2009:31).

Kewajiban pajak tangguhan (deferred tax liabilities) adalah jumlah pajak penghasilan yang terutang untuk periode mendatang sebagai akibat adanya perbedaan temporer kena pajak (Purba, 2009:35), aturan-aturan perpajakan tersebut mengharuskan perusahaan melakukan koreksi-koreksi fiskal (perbedaan permanen) karena terdapat perbedaan konsep pendapatan, cara pengukuran pendapatan, konsep biaya, cara pengukuran biaya, dan cara alokasi biaya antara Standar Akuntansi Keuangan (SAK) dan Peraturan Perpajakan. Selisih laba komersial dan laba fiskal (book-tax differences) dapat menginformasikan tentang diskresi manajemen dalam proses akrual. Selisih tersebut dinamakan koreksi fiskal yang berupa koreksi negatif dan koreksi positif.

Koreksi negatif akan menghasilkan kewajiban pajak tangguhan sedangkan koreksi positif akan menghasilkan aktiva pajak tangguhan (Djamaluddin, 2008:58). Pernyataan Standar Akuntansi Keuangan (PSAK) menjadi pedoman dalam hal menyusun laporan keuangan bagi perusahaan di Indonesia. Dalam hal kepentingan perpajakannya, perusahaan berpedoman pada Peraturan Perpajakan. Perbedaan tersebut mewajibkan manajer dalam membuat laporan keuangan, laporan laba rugi komersil berdasarkan PSAK, dan laporan laba rugi fiskal berdasarkan Peraturan Perpajakan. "Dalam konteks akuntansi atas pajak penghasilan, perbedaan tersebut menghasilkan dua jenis beda, yaitu beda waktu (temporary differences) dan beda tetap (permanent differences)”, (Amanda, 2015).

Beberapa penelitian yang berkaitan dengan pajak kini dan pajak tangguhan telah banyak dilakukan, diantaranya adalah Deviani (2010), Irreza dan Yulianti (2012), Febrianto (2014), Amanda (2015), Anasta (2015), Junery (2016), dan Wang (2016). Penelitian yang dilakukan oleh Amanda (2015) berhasil membuktikan bahwa beban pajak kini berpengaruh signifikan terhadap manajemen laba, sedangkan beban pajak tangguhan tidak berpengaruh terhadap manajemen laba. Anasta (2013) menguji aset pajak tangguhan, liabilitas pajak tangguhan, dan tingkat hutang terhadap manajemen laba. Liabilitas pajak tangguhan berpengaruh terhadap manajemen laba, sedangkan aset pajak tangguhan dan tingkat hutang tidak berpengaruh terhadap manajemen laba. Sedangkan hasil pengujian Timuran dan Muhamad (2015) menunjukkan hasil aset pajak tangguhan signifikan terhadap manajemen laba sedangkan beban pajak kini tidak berpengaruh terhadap manajemen laba. Hasil penelitian terdahulu menunjukkan hasil yang tidak konsisten, model Healy (1985) dianggap memiliki kemampuan yang rendah dari discretionary accrual Anasta (2013), maka peneliti tertarik menguji kembali dengan pengukuran variabel pajak kini menjadi pembeda dengan penelitian terdahulu. Peneliti juga melihat pengaruh antara variabel pajak tangguhan, pajak kini, aset pajak tangguhan, dan liabilitas pajak tangguhan secara terpisah.

\section{TINJAUAN LITERATUR DAN PERUMUSAN HIPOTESIS}

\section{Teori Agensi ( Agency Theory )}

Teori agensi menurut Jensen dan Meckling (1976) dalam Ristiyanti dan Syafruddin (2012) mendefinisikan "hubungan keagenan sebagai sebuah kontrak antara satu orang atau lebih pemilik (principal) yang menyewa orang lain (agent) untuk melakukan beberapa jasa atas nama pemilik yang meliputi pendelegasian wewenang pengambilan keputusan kepada agen”. Eisenhardt (1989) menyatakan bahwa "teori agensi menggunakan tiga asumsi sifat manusia yaitu: (1) manusia pada umumnya mementingkan diri sendiri (self interest), (2) manusia memiliki daya pikir terbatas mengenai persepsi masa mendatang (bounded rationality), dan (3) manusia selalu menghindari resiko (risk averse)". Dimana manajer sebagai manusia kemungkinan besar akan bertindak oportunistik, yaitu mengutamakan kepentingan pribadinya Iline dan Susanto (2019). Dari penjelasan tersebut dapat disimpulkan bahwa konflik agensi yang seringkali terjadi antara manajer dengan pihak pemegang saham dipicu dengan adanya sifat dasar tersebut. 
Adanya perbedaan kepentingan dan informasi antara prinsipal dan agen memacu agen untuk memikirkan bagaimana angka akuntansi yang dihasilkan dapat lebih memaksimalkan kepentingannya. Cara yang dapat dilakukan agen untuk mempengaruhi angka-angka akuntansi dapat berupa rekayasa laba atau manajemen laba dalam laporan keuangan Anasta (2013).

\section{Teori Kepatuhan (Compliance Theory)}

Hubungan teori kepatuhan dengan perpajakan adalah dalam pemungutan pajak semua wajib pajak harus patuh, taat, dan menuruti peraturan perpajakan yang berlaku, hal tersebut merupakan pemenuhan kewajiban perpajakan yang dilakukan oleh pembayar pajak dalam rangka memberikan kontribusi bagi pembangunan yang diharapkan di dalam pemenuhannya diberikan secara sukarela. Kepatuhan wajib pajak menjadi aspek penting mengingat sistem perpajakan Indonesia menganut self assessment system.

\section{Manajemen Laba}

Menurut Scott (2000) "manajemen laba adalah suatu tindakan manajemen untuk memilih kebijakan akuntansi dari suatu standar tertentu dengan tujuan memaksimalisasi kesejahteraan pihak manajemen dan atau nilai pasar perusahaan. Scott (2003) dalam Pambudi (2013) mengemukakan beberapa motivasi yang mendorong manajer perusahaan untuk melakukan manajemen laba, yaitu:

a. Bonus scheme adanya asimetri informasi antara manajer dengan investor berkenaan dengan laba bersih yang akan dilaporkan dalam laporan keuangan, dimana pihak manajer mempunyai informasi lebih sebelum dilaporkan dalam laporan keuangan sedangkan pihak luar dan investor tidak bisa mengetahui sampai mereka membaca laporan keuangan tersebut.

b. Debt convenant atau kontrak jangka panjang merupakan perjanjian yang dibuat antara kreditur dan debitur dengan tujuan untuk melindungi kepentingan kreditur atas tindakan-tindakan yang dilakukan manajer perusahaan.

c. Political motivation dengan aspek politis tidak dapat dipisahkan dari operasional suatu perusahaan, khususnya perusahaan dalam skala besar dan industri strategis yang aktivitasnya melibatkan hajat hidup orang banyak.

d. Taxation motivation, masalah perpajakan merupakan salah satu alasan mengapa pihak manajemen perusahaan berusaha mengurangi tingkat laba bersih yang dilaporkan agar nilai pajak yang harus ditanggung dapat diperkecil.

e. Pergantian CEO (chief executive officer) dengan adanya pergantian CEO biasanya diikuti dengan fenomena manajemen laba dimana seorang CEO yang mendekati masa akhir jabatannya biasanya berusaha memaksimalkan laba yang dilaporkan agara tingkat bonus yang mereka terima bisa lebih tinggi.

f. Initial public offerings (IPO). Perusahaan yang melakukan penawaran saham untuk pertama kalinya biasanya dihadapkan pada masalah penentuan harga saham yang ditawarkan, karena perusahaan tersebut belum mempunyai harga saham. Untuk itu perusahaan cenderung melakukan manajemen laba untuk memperoleh harga saham sesuai dengan keinginannya, dengan cara memanipulasi tingkat laba bersih.

g. Mengkomunikasikan informasi kepada investor. Efisiensi pasar relatif terhadap ketersediaan infomasi secara publik. Jika manajemen laba dapat mengungkapkan inside information, maka hal tersebut dapat meningkatkan informasi perlaporan keuangan.

Menurut Scott (2000) dalam Yushita (2010) terdapat beberapa pola manajemen laba, yaitu Taking a bath CEO pengganti cenderung mengambil kebijakan untuk pembiayaan kos yang sebelumnya ditangguhkan, memperkecil risiko pitung tidak tertagih dengan memperbesar cadangan, meninjau kembali akuntansi sediaan dengan melakukan cek fisik ketat juga kebijakan akuntansi aktiva tetapnya. Income decreasing method (metode menurunkan pendapatan). Income increasing method (metode menaikkan pendapatan). Income smoothing (perataan laba) 
Penelitian Healy (1985) menunjukkan bahwa manajer memiliki insentif untuk meratakan laba agar tetap berada di antara batas bawah (bogy) dan batas atas (cup) skema bonus. Manajer yang tidak suka risiko (risk averse) lebih menykai laba yang tidak berfluktuasi.

\section{Beban Pajak Kini}

Beban Pajak Kini adalah jumlah Pajak yang harus dibayar oleh Wajib Pajak yang dihitung dari Penghasilan Kena Pajak hasil rekonsiliasi fiskal yang dikalikan tarif pajak. Beban Pajak Komersil adalah jumlah beban pajak yang dihitung oleh Wajib pajak dari Penghasilan Sebelum pajak dalam laporan Keuangan Komersil dikalikan dengan tarif pajak Penghasilan kena pajak atau laba fiskal diperoleh dari hasil koreksi fiskal terhadap laba bersih sebelum pajak berdasarkan laporan keuangan komersial (laporan akuntansi).

Koreksi fiskal harus dilakukan karena adanya perbedaan perlakuan atas pendapatan maupun biaya yang berbeda antara standar akuntansi dengan peraturan perpajakan yang berlaku Suandy (2011) dalam Amanda (2015). Dalam beberapa hal, wajib pajak mempunyai kebebasan di dalam membuat kebijakan-kebijakan akuntansi yang berkaitan dengan penentuan saat pengakuan pendapatan dan biaya, meskipun kebijakan akuntansi yang telah ditetapkan harus diterapkan secara taat asas atau konsisten dari tahun ke tahun (Lindira dan Ketut, 2014:251) dalam Junery (2016). Hal tersebut menjadi peluang bagi perusahaan untuk melakukan manajemen laba, menaikkan dan menurunkan laba perusahaan melalui pengakuan pendapatan dan beban.

Junery (2016) mampu membuktikan bahwa pajak kini berpengaruh terhadap manajemen laba, sedangkan penelitian yang dilakukan oleh Febrianto (2014) tidak ada pengaruh variabel beban pajak kini terhadap manajemen laba.

\section{$\boldsymbol{H}_{\boldsymbol{i}}$ : Diduga terdapat pengaruh beban pajak kini terhadap manajemen laba.}

Beban Pajak Tangguhan

Secara konseptual manajemen melakukan praktik manajemen laba karena dilandasi oleh teori keagenan yang menyebabkan adanya asimetri informasi dan konflik kepentingan yang terjadi antara agent dengan principal. Keadaan tersebut didukung pula dengan kelonggaran yang diberikan oleh SAK kepada perusahaan untuk memilih metode akuntansi dalam menyusun laporan keuangan komersial, sedangkan untuk kepentingan perpajakan laporan keuangan fiskal disusun oleh perusahaan berdasarkan aturan perpajakan Febrianto (2014).

Berdasarkan PSAK No. 46, Selisih antara Beban Pajak kini dan dan beban pajak komersil adalah Beban Pajak Tangguhan. Phillips at al (2003) dalam (Aristanti dan Cynthia, 2012) menyatakan bahwa beban pajak tangguhan dapat digunakan dan memiliki kemampuan yang sangat baik dalam mendeteksi manajemen laba yang dilakukan perusahaan dalam memenuhi dua tujuan, yaitu (1) untuk menghindari penurunan laba dan (2) untuk menghindari kerugian. Junery (2016) dalam penelitiannya mampu membuktikan bahwa beban pajak tangguhan memiliki pengaruh terhadap manajemen laba.

\section{$\boldsymbol{H}_{2}$ : Diduga terdapat pengaruh pajak tangguhan terhadap manajemen laba.}

Aset Pajak Tangguhan

Pengakuan aset atau kewajiban pajak tangguhan didasarkan fakta bahwa adanya kemungkinan pemulihan aset atau pelunasan kewajiban yang mengakibatkan pembayaran pajak periode mendatang menjadi lebih kecil atau besar, apabila ada kemungkinan pembayaran pajak yang lebih kecil pada masa yang akan datang, maka berdasarkan standar akuntansi keuangan, harus diakui sebagai suatu aset Timuriana dan Muhamad (2015). Aset pajak tangguhan meningkat ketika 
perusahaan mempercepat pengakuan pendapatan atau menangguhkan pengakuan beban (mempercepat beban atau menangguhkan pendapatan) untuk kepentingan akuntansi dibandingkan dengan kepentingan perpajakan perusahaan tersebut Yulianti (2005).

Aset pajak tangguhan tidak dapat diakui jika timbul dari pengakuan awal aktiva atau pengakuan awal liabilitas dalam transaksi yang bukan merupakan kombinasi bisnis, dan pada saat transaksi yang dampaknya tidak mempengaruhi laba akuntansi maupun laba kena pajak (IAI, 2013). Atas dasar hal tersebut, judgment diperlukan dalam menaksir besaran aset pajak tangguhan yang dapat direalisasi. Suranggane (2007) mengemukakan bahwa aset pajak tangguhan dijadikan proksi sebagai indikator dari praktik manajemen laba yang dilakukan perusahaan. Aset pajak tangguhan yang jumlahnya diperbesar oleh manajemen dimotivasi adanya pemberian bonus, beban politis atas besarnya perusahaan dan minimalisasi pembayaran pajak agar tidak merugikan perusahaan.

Penelitian yang dilakukan oleh Timuriana dan Muhamad (2015) menunjukkan hasil yang signifikan, bahwa tindakan manajemen laba dipengaruhi oleh variabel aset pajak tangguhan. Sedangkan penelitian yang dilakukan oleh Anasta (2015), manajemen laba tidak dipengaruhi oleh aset pajak tangguhan yang diproksi dengan akrual diskresioner dalam hal untuk menghindari kerugian perusahaan. Anasta (2015) mengemukakan bahwa perusahaan sampel cenderung menghindari terjadinya koreksi fiskal yang besar yang berdampak pada besarnya jumlah pajak yang harus dibayarkan oleh perusahaan.

\section{$\boldsymbol{H}_{3}$ : Diduga terdapat pengaruh aset pajak tangguhan terhadap manajemen laba.}

\section{Liabilitas Pajak Tangguhan}

Liabilitas pajak tangguhan suatu perusahaan meningkat ketika pelaporan laba komersilnya lebih tinggi dibandingkan dengan laba menurut pajak. Liabilitas pajak tangguhan dihitung dengan mengalikan jumlah perbedaan temporer dengan tarif pajak. Semakin besar persentase deferred tax liabilities terhadap total beban pajak perusahaan menunjukkan standar akuntansi yang semakin liberal Yulianti (2004) dalam Anasta (2015). Hal tersebut dapat dikaitan dengan salah satu motivasi manajer melakukan manajemen laba yaitu bonus scheme dengan membesarkan atau mengecilkan jumlah beban pajak tangguhan yang diakui dalam laporan laba rugi akibat dari perbedaan antara laba akuntansi dengan laba fiskal yang memiliki hubungan positif dengan insentif pelaporan keuangan seperti pemberian bonus.

Anasta (2015) melakukan pengujian variabel liabilitas pajak tangguhan (deffered tax liabilities) terhadap manajemen laba, dan menunjukkan bahwa liabilitas pajak tangguhan memiliki pengaruh yang signifikan terhadap tindakan melakukan manajemen laba dalam hal untuk menghindari kerugian perusahaan. Deferred tax liabilities mengakibatkan tingkat laba yang diperoleh menurun dengan demikian memiliki peluang yang lebih besar untuk mendapatkan laba yang lebih besar di masa yang akan datang dan mengurangi besarnya pajak yang dibayarkan Yulianti (2004) dalam Anasta (2015).

\section{$\boldsymbol{H}_{4}$ : Diduga terdapat pengaruh liabilitas pajak tangguhan terhadap manajemen laba.}

\section{METODE PENELITIAN}

Penelitian menggunakan metode kuantitatif. Penelitian kuantitatif adalah penyelidikan atau investigasi yang dikelola, sistematis, berdasarkan data, kritis, objektif, dan ilmiah terhadap suatu masalah spesifik, yang bertujuan menemukan jawaban atau solusi terkait yang umumnya diperoleh melalui pertanyaan terstruktur (Sekaran, 2009). Penelitian ini dilakukan di Bursa Efek Indonesia (BEI). Pemilihan tempat tersebut ditentukan berdasarkan objek penelitian yang akan diteliti. Objek penelitian akan difokuskan pada perusahaan yang terdaftar di BEI dari periode 2013-2017. 
Penelitian ini menggunakan data perusahaan barang konsumsi yang bersumber sebagai data sekunder. Sektor barang konsumsi (consumer goods) merupakan salah satu sektor penting bagi perekonomian nasional. Produk Domestik Bruto (PDB) sektor makanan dan minuman pada 2016 mencapai $\mathrm{Rp} 586,5$ triliun atau 6,2\% dari total PDB nasional senilai Rp 9.433 triliun. (www.katadata.co.id, 2018). Data dari Badan Pusat Statistik menunjukkan rata-rata 50,94\% pengeluaran perbulan masyarakat Indonesia ditujukan untuk barang konsumsi (www.bps.go.id, 2017). Peningkatan indeks industri barang konsumsi mengalahkan indeks sektor pekebunan, pertambangan, properti, industri keuangan serta perdagangan, jasa dan investasi. Hal ini yang menjadikan industri barang konsumsi menarik untuk diteliti. Data tersebut diperoleh dan dikumpulkan dengan cara dokumentasi terhadap dokumen-dokumen yang berhubungan dengan penelitian. Semua yang berkaitan dengan laporan keuangan dan annual report tersebut diperoleh dari website Bursa Efek Indonesia dengan alamat http://www.idx.co.id. Pada penelitian ini, metode pengambilan sampel adalah purposive sampling. Berikut adalah beberapa kriteria sampel tersebut, antara lain:

Tabel 1 Kriteria Sampel

\begin{tabular}{cl}
\hline No & \multicolumn{1}{c}{ Kriteria Sampel } \\
\hline 1 & $\begin{array}{l}\text { Perusahaan kelompok industri barang konsumsi yang terdaftar di BEI dari tahun } 2012- \\
2017\end{array}$ \\
2 & $\begin{array}{l}\text { Perusahaan yang menerbitkan laporan keuangan tahunan yang dinyatakan dalam rupiah } \\
\text { dan berakhir pada tanggal 31 Desember selama periode pengamatan. }\end{array}$ \\
3 & $\begin{array}{l}\text { Perusahaan yang menampilkan akun aset pajak tangguhan dan liabilitas pajak tangguhan } \\
\text { selama periode pengamatan. }\end{array}$ \\
4 & $\begin{array}{l}\text { Perusahaan menerbitkan laporan keuangan tahunan secara lengkap dan berakhir pada } \\
\text { tanggal 31 Desember selama periode dari tahun 2013-2017. }\end{array}$ \\
\hline
\end{tabular}

\section{Teknik Analisis}

Variabel Dependen

Manajemen laba yang diproksikan dengan menggunakan discretionary accruals dan dihitung dengan menggunakan modified jones model. Modified Jones model dapat mendeteksi manajemen laba lebih baik dibandingkan dengan model-model lainnya. Untuk mengukur discretionary accruals mengacu pada penelitian Dechow et al. (1995).

$$
\mathrm{TAC}=\mathrm{Nit}-\mathrm{CFO} \text { it }
$$

Nilai Total Accrual (TAC) yang diestimasi dengan persamaan regresi OLS (Ordinary Least Square) sebagai berikut:

TAit/Ait-1 $=\beta 1(1 /$ Ait-1 $)+\beta 2(\Delta$ Revt/ Ait-1) $+\beta 3($ PPEt $/$ Ait- 1$)+\varepsilon$

NDAit $=\beta 1(1 /$ Ait-1 $)+\beta 2(\Delta$ Revt/ Ait-1 $-\Delta$ Rect/ Ait-1 $)+\beta 3($ PPEt $/$ Ait-1) ................... [2]

DAit $=$ TAit/ Ait-1 - NDAit........................................................................................ [3]

Keterangan:

DAit $=$ Discretionary accruals perusahaan I pada periode ke-t

NDAit $\quad=\quad$ Non discretionary accruals perusahaan I pada periode ke-t

TAit $=$ Total accrual perusahaan i pada periode ke-t

Nit $=$ Laba bersih perusahaan i pada periode ke-t

CFOit $=\quad$ Aliran kas dari aktivitas operasi perusahaan i pada periode ke-t

Ait-1 = Total aktiva perusahaan i pada periode ke $\mathrm{t}-1$

$\Delta$ Revt $=$ Perubahan pendapatan perusahaan i pada periode ke-t

PPEt $=$ Aktiva tetap perusahaan pada periode ke-t 


$$
\begin{array}{lll}
\Delta \text { Rect } & = & \text { Perubahan piutang perusahaan i pada periode ke-t } \\
\mathrm{E} & = & \text { Error }
\end{array}
$$

Variabel Independen

a. Pajak Kini yang dimaksud dalam penelitian ini diukur menggunakan skala rasio, diperoleh dari perhitungan delta beban pajak kini pada periode laporan keuangan tertentu dibagi dengan total aset periode sebelumnya.

b. Pajak Tangguhan yang dimaksud dalam penelitian ini diukur menggunakan skala rasio, dan diperoleh dari perhitungan delta beban pajak tangguhan pada periode laporan keuangan tertentu dibagi dengan total aset periode sebelumnya, mengacu pada penelitian Yuliati (2005) dalam Budiarti 2013.

c. Aset Pajak Tangguhan yang dimaksud dalam penelitian ini diukur dengan menggunakan skala rasio. Dihitung dengan menggunakan indikator membobot delta aset pajak tangguhan periode kini dengan total asset pajak tangguhan periode sebelumnya, mengacu pada penelitian Suranggane (2007).

d. Liabilitas Pajak Tangguhan yang dimaksud dalam penelitian ini diukur dengan menggunakan skala rasio. Dihitung dengan menggunakan indikator membobot beban pajak tangguhan dengan total aktiva atau total aset, mengacu pada penelitian Yulianti (2004).

Metode analisis data yang digunakan untuk menguji hipotesis dalam penelitian ini adalah: (1) Statistik Deskriptif; (2) Uji Asumsi Klasik (normalitas, autokorelasi, heteroskedastisitas, dan multikolinearitas). Untuk menguji hipotesis digunakan metode reresi linier berganda dengan program SPSS versi 23.0. Untuk mengetahui apakah model regresi benar-benar menunjukan hubungan yang signifikan dan representatif, maka diperlukan pengujian Analisis Adjusted R Square, Uji Model (Uji F), dan Uji t. Model penelitian ini dapat dirumuskan sebagai berikut:

$$
\text { DAit }=\alpha+\beta 1 \text { CTit }+\beta 2 \text { DTit }+\beta 3 \text { DTAit }+\beta 4 \text { DTLit } \varepsilon i
$$

\section{HASIL DAN PEMBAHASAN}

Analisis Deskriptif

Analisis deskriptif dilakukan agar memberikan gambaran atau deskriptif terhadap variabelvariabel yang digunakan dalam penelitian ini. Hasil analisis statistik deskriptif dalam penelitian, dapat dilihat pada tabel di bawah ini:

Tabel 2 Statistik Deskriptif Variabel Penelitian

Descriptive Statistics

\begin{tabular}{llllll}
\hline Variabel & $\mathrm{N}$ & Minimum & Maximum & Mean & Std. Deviation \\
\hline DA & 135 & -.262 & .431 & -.01127 & .094221 \\
CT & 135 & .000 & .208 & .04714 & .040083 \\
DT & 135 & -.026 & .030 & -.00070 & .005515 \\
DTA & 135 & -1.920 & .979 & .14987 & .389571 \\
DTL & 135 & .000 & .212 & .01021 & .020900 \\
\hline
\end{tabular}

Sumber : Data yang diolah, 2018.

Keterangan :

$\begin{array}{ll}\text { DA } & : \text { discretionary accrual } \\ \text { CT } & : \text { current tax } \\ \text { DT } & : \text { deffered tax } \\ \text { DTA } & : \text { deffered tax asset }\end{array}$


DTL : deffered tax liabilities

Pajak kini (current tax) memiliki nilai minimum 0,000 dan nilai maksimum sebesar 0,208. Nilai rata-rata variabel pajak kini adalah 0,04714 dengan standar deviasi 0,040083, hal ini menunjukkan simpangan data penelitian sebesar 4,01\%. Pajak tangguhan (deffered tax) memiliki nilai minimum sebesar $-0,026$ dan nilai maksimum sebesar 0,030 dengan rata-rata -0,00070 dan standar deviasi 0,005515 yang menunnjukkan simpangan data penelitian yang cukup rendah yaitu sebesar $0,55 \%$. Aset pajak tangguhan (deffered tax asset) pada perusahaan sampel memiliki nilai minimum -1,920 dan nilai maksimum sebesar 0,979 dengan nilai rata-rata 0,14987 menunjukkan pada perusahaan sampel terdapat koreksi positif yang lebih tinggi atas perbedaan temporer hasil rekonsiliasi fiskal sebesar 14,99\%. Standar deviasi aset pajak tangguhan sebesar 0,389571. Liabilitas pajak tangguhan (deffered tax liabilities) memiliki nilai minimum 0,000 dan nilai maksimum iabilitas Pajak Tangguhan adalah sebesar 0,212, dengan nilai rata-rata 0,01021, terdapat perbedaan koreksi negatif atas perbedaan temporer hasil rekonsiliasi fiskal sebesar $1,02 \%$. Standar deviasi liabilitas pajak tangguhan adalah sebesar 0,020900 .

Manajemen laba yang diproksikan dengan menggunakan discretionary accrual menunjukkan nilai rata-rata -0,01127 dengan standar deviasi 0,094221. Sedangkan nilai minimum -0,262 dan nilai maksimum 0,431. Untuk mengetahui apakah perusahaan sampel melakukan tindakan manajemen laba dapat dilihat dari nilai minimum dan maksimum, jika rentang yang cukup jauh mengindikasikan tidak melakukan manajemen laba sedangkan sebaliknya apabila rentang yang semakin dekat maka mengindikasikan manajemen laba. Nilai discretionary accrual yang bernilai positif dan negatif menunjukkan bahwa terdapat DA yang menaikkan laba (income increasing) dan menurunkan laba (income decreasing). Berdasarkan tabel diatas mengindikasikan sebagian besar perusahaan sampel melakukan manajemn laba dengan pola income increasing. Nilai standar deviasi yang lebih besar dibandingkan dengan nilai rata-rata merupkan representasi yang kurang baik dari keseluruhan data.

Analisa Uji Asumsi Klasik

Uji asumsi klasik digunakan untuk menguji, apakah model regresi yang digunakan dalam penelitian ini layak diuji atau tidak. Hasil pengujian asumsi klasik disajikan pada tabel 3 berikut ini:

Tabel 3 Hasil Pengujian Asumsi Klasik

\begin{tabular}{|c|c|c|c|c|}
\hline Pengujian & \multicolumn{3}{|c|}{ Hasil Pengujian } & Simpulan \\
\hline a. Normalitas & Asymp. Sig. (2-tailed) & \multicolumn{2}{|c|}{0,200} & Data berdistribusi normal \\
\hline \multirow{5}{*}{ b.Multikolonieritas } & & Tolerance & VIF & \multirow{5}{*}{$\begin{array}{l}\text { Nilai VIF masih dibawah } 10 \\
\text { atau nilai tolerance diatas } 0,1 \\
\text { mengindikasi kan tidak } \\
\text { terjadi multiko- linieritas. }\end{array}$} \\
\hline & Pajak Kini & 0,883 & 1,132 & \\
\hline & Pajak Tangguhan & 0,873 & 1,146 & \\
\hline & Aset Pajak Tangguhan & 0,918 & 1,089 & \\
\hline & Liabilitas Pajak Tangguhan & 0,895 & 1,118 & \\
\hline c. Autokorelasi & Durbin-Watson (DW) & \multicolumn{2}{|c|}{1,850} & Tidak terdapat autokore- lasi \\
\hline d.Heteroskedastisitas & \multicolumn{3}{|c|}{$\begin{array}{l}\text { Titik-titik pada grafik relatif menyebar baik di } \\
\text { atas sumbu nol maupun di bawah sumbu nol. }\end{array}$} & $\begin{array}{l}\text { Tidak memiliki gangguan } \\
\text { heteroskedastisitas }\end{array}$ \\
\hline
\end{tabular}

Sumber : Data yang diolah, 2018

Dari tabel 3 dapat disimpulkan bahwa data yang digunakan untuk penelitian ini berdistribusi normal. Hal ini dapat dilihat dari nilai Asymp. Sig. (2-tailed) diatas 0,05 yaitu sebesar 0,200. Uji multikolinearitas bertujuan untuk menguji apakah model regresi ditemukan adanya korelasi antar variabel bebas. Pengujian ini dengan melihat nilai tolerance dan variance inflation factor (VIF). Berdasarkan tabel 3 di atas, tolerance value $>0,1$ dan VIF $<10$, sehingga dapat disimpulkan bahwa seluruh variabel independen tidak terdapat hubungan multikolinearitas dan dapat digunakan dalam penelitian ini. Uji autokorelasi menunjukkan adanya korelasi antara kesalahan pengganggu pada periode t dengan kesalahan pada periode t-1. Dasar regresi yang baik tidak terjadi autokorelasi. 
Apabila terjadi autokorelasi maka akan mengakibatkan pengaruh secara parsial menjadi kurang akurat. Penelitian ini menggunakan uji Durbin-Watson untuk mencari ada tidaknya autokorelasi dalam penelitian yaitu dengan membandingkan nilai DWhitung dengan DWtabel. Berdasarkan hasil pengujian autokorelasi, diketahui nilai DWhitung sebesar 2,013 dan dibandingkan dengan DWtabel. Diketahui $\mathrm{n}=135, \mathrm{k}=4$ dengan $\alpha=0,05$ diperoleh nilai DWtabel $\mathrm{du}=1,7645$. Sehingga dapat disimpulkan bahwa model penelitian ini tidak terdapat gejala autokorelasi. Uji heteroskedastisitas bertujuan menguji apakah dalam model regresi terjadi ketidaksamaan variance dari residual satu pengamatan ke pengamatan yang lain. Pengujian ini melihat grafik scatterplot antar nilai prediksi variabel terikat (dependen) yaitu ZPRED dengan residualnya SRESID. Adapun hasil uji heterokedastisitas dalam penelitian ini disajikan pada Gambar 1. Dengan melihat grafik scatterplot, terlihat titik-titik menyebar secara acak, serta tersebar baik di atas maupun di bawah angka 0 pada sumbu Y. Dari pengujian data variabel X maupun Y, maka dapat disimpulkan tidak terdapat gejala heteroskedastisitas pada model regresi yang digunakan.

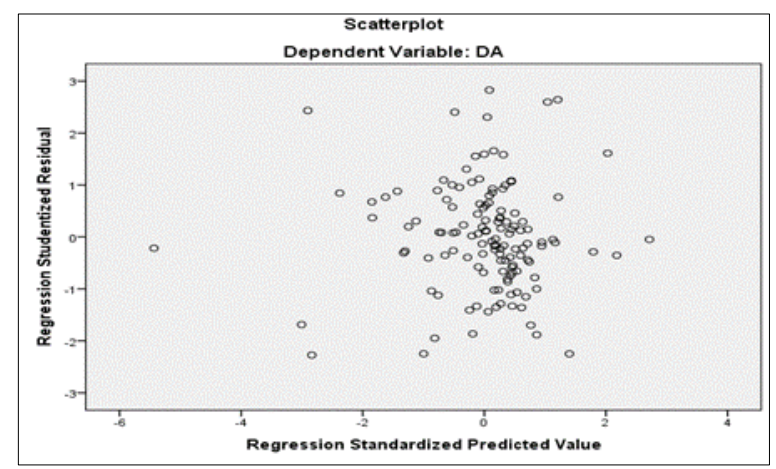

Sumber : Data yang diolah, 2018

Gambar 1 Scatterplot

Uji Model

Untuk menguji hipotesis dalam penelitian ini menggunakan analisis regresi berganda yang digunakan untuk menguji pengaruh pajak kini, pajak tangguhan, aset pajak tangguhan, dan liabilitas pajak tangguhan terhadap manajemen laba. Berikut hasil pengujian model regresi linear berganda untuk semua variabel yang digunakan:

Tabel 4 Hasil Pengujian Model Regresi Linear Berganda

\begin{tabular}{l|l|l|l}
\hline Variabel & Koefisien Regresi & t & Sig \\
\hline Pajak Kini & $-0,182^{* *}$ & $-2,080$ & 0,040 \\
\hline Pajak Tangguhan & $-0,261^{* *}$ & $-2,959$ & 0,004 \\
\hline Aset Pajak Tangguhan & $-0,165^{*}$ & $-1,923$ & 0,057 \\
\hline Liabilitas Pajak Tangguhan & $-0,087$ & $-0,998$ & 0,320 \\
\hline Koefisien Determinasi (R $\left.{ }^{2}\right)$ & $0,145 \quad \begin{array}{l}\text { Keterangan : } \\
\text { Adjusted (R2) }\end{array}$ & $0,118 \quad$ : Menunjukkan nilai signifikansi pada 0,01 \\
F Hitung & $5,340 \quad *$ * : Menunjukkan nilai signifikansi pada 0,05 \\
Siginifikansi & $0,001 \quad *^{* *}$ : Menunjukkan nilai signifikansi pada 0,10 \\
\hline
\end{tabular}

Sumber: Data yang diolah, 2018

Uji Anova atau uji kelayakan model pada dasarnya menunjukkan apakah semua variabel independen yang digunakan dalam penelitian mempunyai pengaruh secara simultan terhadap variabel dependen. Pengujian ini dilakukan dengan menggunakan tingkat signifikansi 5\%. Pada tabel 4 di atas, menunjukkan bahwa nilai signifikansi sebesar $0,001<0,050$ sehingga dapat disimpulkan model regresi dapat digunakan untuk mengindikasi manajemen laba. R-square 
digunakan untuk melihat sejauh mana variabel bebas mampu menerangkan keragaman variabel terikatnya. Terlihat pada table.7,nilai dari Adjusted R Square sebesar 0,118, ini berarti sebesar 11,80 persen (\%) variasi variabel pajak kini, pajak tangguhan, aset pajak tangguhan, dan liabilitas pajak tangguhan menjelaskan variabel praktek manajemen laba, sedangkan sisanya sebesar 88,20 persen (\%) dipengaruhi oleh variabel lain yang tidak dimasukkan dalam penelitian.

\section{Uji Hipotesis}

Uji t pada dasarnya menunjukkan seberapa jauh pengaruh satu variabel penjelas secara individual dalam menerangkan variasi variabel dependen. Pengujian ini dilakukan dengan menggunakan tingkat signifikansi $5 \%$ dan $10 \%$. Dari uji t pada table.7 di atas maka dapat ditarik kesimpulan sebagai berikut:

\section{Pajak Kini dan Manajemen Laba}

Hipotesis pertama yang diajukan menyatakan bahwa pajak kini berpengaruh terhadap manajemen laba. Dari hasil penelitian yang dilakukan diperoleh nilai signifikansi sebesar 0,040 atau lebih kecil dari 0,05 , sehingga hipotesis yang diajukan dalam penelitian ini diterima. Hasil analisis statistik deskriptif menunjukkan bahwa perusahaan yang menjadi sampel dalam penelitian ini melakukan manajemen laba dengan menghindari penurunan laba. Hasil penelitian ini konsisten dengan hasil penelitian yang dilakukan oleh Amanda (2015) yang menyatakan bahwa beban pajak kini mampu mendeteksi kemungkinan perusahaan melakukan manajemen laba karena beban pajak kini merefleksikan penghasilan kena pajak yang merupakan hasil rekonsiliasi beda waktu sekaligus beda tetap terhadap laba menurut akuntansi. Pada umumnya penghasilan kena pajak menghasilkan nilai yang lebih besar dibandingkan dengan laba komersil, karena terdapat koreksi fiskal sesuai dengan Undang-Undang Nomor 7 Tahun 1983 tentang Pajak Penghasilan dalam pasal 9. Penilitan ini juga sejalan dengan penelitian Negara (2017) dan Junery (2016), bahwa pajak kini berpengaruh terhadap manajemen laba.

Pajak Tangguhan dan Manajemen Laba

Hipotesis kedua yang diajukan menyatakan bahwa pajak tangguhan berpengaruh terhadap manajemen laba. Dari hasil penelitian yang dilakukan diperoleh nilai signifikansi sebesar 0,004 atau lebih kecil dari 0,05, sehingga hipotesis yang diajukan dalam penelitian ini diterima. Berdasarkan hasil penelitian ini pajak tangguhan berpengaruh terhadap manajemen laba. Hasil penelitian ini tidak konsisten terhadap hasil penelitian yang dilakukan oleh Amanda (2015) dan Arief (2014). Arief (2014) mengemukakan kemungkinan pajak tangguhan tidak berpengaruh terhadap manajemen laba disebabkan karena telah berlakunya tarif tunggal di dalam menghitung beban pajak, yaitu 25\% dari Penghasilan Kena Pajak sebelum berlakunya tarif tunggal 25\%.

Hasil pengujian pengaruh pajak tangguhan terhadap manajemen laba menunjukkan nilai signifikansi 0,004, hal ini menunjukkan bahwa . Signifikannya pengaruh pajak tangguhan, menunjukkan bahwa taxation motivation yang mendorong perusahaan sampel melakukan tindakan manajemen laba, yaitu pihak manajemen perusahaan berusaha mengurangi tingkat laba bersih yang dilaporkan agar nilai pajak yang harus ditanggung dapat diperkecil, Scott (2003).

Nilai beban pajak tangguhan yang merupakan koreksi negatif terhadap laba fiskal muncul karena nilai pajak komersil lebih tinggi dibandingkan dengan penghasilan kena pajak. Penelitian ini konsisten dengan hasil penelitian Negara (2017) yang menemukan bahwa telah terjadi manajemen laba dengan tujuan pelaporan kerugian pada perusahaan-perusahaan yang terdaftar di BEI tahun 2013-2015. 
Aset Pajak Tangguhan dan Manajemen Laba

Hipotesis ketiga yang diajukan menyatakan bahwa aset pajak tangguhan berpengaruh terhadap manajemen laba. Dari hasil penelitian yang dilakukan diperoleh nilai signifikansi sebesar 0,013 atau lebih kecil dari tingkat signifikansi $\alpha=0,10$, sehingga hipotesis yang diajukan dalam penelitian ini diterima. Berdasarkan hasil penelitian ini, aset pajak tangguhan berpengaruh terhadap manajemen laba. Hal tersebut merepresentasikan bahwa aset pajak tangguhan dapat dijadikan celah untuk melakukan manajemen laba. Hasil penelitian ini tidak konsisten dengan hasil penelitian yang dilakukan oleh Anasta (2013) yang menyatakan bahwa manajer mempertimbangkan secara detail kemungkinan resiko-resiko dan kerugian yang lebih besar untuk merekayasa komponen aset pajak tangguhan dalam upaya meningkatkan laba tersebut.

Variabel aset pajak tangguhan yang berpengaruh terhadap manajemen laba mencerminkan bahwa perusahaan sampel penelitian memanfaatkan celah dari kebijakan yang ada dalam PSAK No.46. manajer memanfaatkan cadangan aset pajak tangguhan pada laporan keuangan komersil untuk melakukan tindakan manajemen laba. Penelitian ini konsisten dengan hasil penelitian Timuriana (2015) yang mengemukakan bahwa pajak yang seharusnya dibayarkan pada periode sekarang dialihkan pada periode mendatang dengan demikian laba perusahaan pun akan meningkat karena beban pajak yang harus dibayarkan lebih kecil.

Liabilitas Pajak Tangguhan dan Manajemen Laba

Hipotesis keempat yang diajukan menyatakan bahwa liabilitas pajak tangguhan berpengaruh terhadap manajemen laba. Nilai signifikansi pada tabel 4 menunjukkan sebesar 0,320 atau lebih besar dari 0,05, sehingga hipotesis yang diajukan dalam penelitian ini ditolak. Berdasarkan hasil penelitian ini, liabilitas pajak tangguhan tidak berpengaruh terhadap manajemen laba. Hasil penelitian ini tidak konsisten dengan hasil penelitian yang dilakukan oleh Anasta (2013) yang menyatakan bahwa liabilitas pajak tangguhan memiliki pengaruh yang signifikan terhadap tindakan manajemen laba dalam hal untuk menghindari kerugian perusahaan.

Perusahaan sampel pada periode pengamatan tidak menjadikan liabilitas pajak tangguhan sebagai sarana untuk melakukan tindakan manajemen laba, hal tersebut dimungkinkan karena pada umumnya laporan laba rugi perusahaan yg direkonsiliasi secara fiskal akan menghasilkan koreksi positif dimana beban menjadi lebih rendah, sehingga hasil penghasilan kena pajaknya menjadi lebih tinggi dibandingkan dengan beban pajak komersil.

Hasil penelitian ini konsisten terhadap hasil penelitian yang dilakukan oleh Timuriana (2015) yang mengemukakan bahwa perpajakan hanya mengakui beban pajak pada periode tersebut dan tidak mengakui adanya beban pajak tangguhan.Hasil penelitian ini konsisten terhadap hasil penelitian yang dilakukan oleh Timuriana (2015) yang mengemukakan bahwa perpajakan hanya mengakui beban pajak pada periode tersebut dan tidak mengakui adanya beban pajak tangguhan Hasil penelitian ini tidak konsisten dengan hasil penelitian yang dilakukan oleh Anasta (2013) yang menyatakan bahwa liabilitas pajak tangguhan memiliki pengaruh yang signifikan terhadap tindakan manajemen laba dalam hal untuk menghindari kerugian perusahaan.

\section{KESIMPULAN}

Berdasarkan hasil analisis dan pembahasan yang telah diuraikan pada bab sebelumnya, beberapa kesimpulan yang dapat diambil dari penelitian ini yaitu, analisis uji t menunjukkan bahwa variabel pajak kini (X1) berpengaruh terhadap manajemen laba (Y). Hal ini ditunjukkan oleh nilai t sebesar -2,080 dan p-value sebesar 0,040, maka hipotesis terbukti dan diterima. Variabel pajak tangguhan (X2) berpengaruh terhadap manajemen laba (Y). Hal ini ditunjukkan oleh nilai t sebesar -2,959 dan p-value sebesar 0,004, maka hipotesis terbukti dan diterima. Variabel aset pajak tangguhan (X3) berpengaruh terhadap manajemen laba (Y) dengan tingkat signifikansi $\alpha=0,10$. Hal ini ditunjukkan oleh nilai t sebesar -1,923 dan p-value sebesar 0,057, maka hipotesis terbukti 
dan diterima. Variabel liabilitas pajak tangguhan (X4) tidak berpengaruh terhadap manajemen laba (Y). Hal ini ditunjukkan oleh nilai t sebesar -0,998 dan p-value sebesar 0,320, maka hipotesis tidak terbukti dan ditolak. Hasil analisis uji $\mathbf{F}$ menunjukkan bahwa variabel pajak kini, pajak tangguhan, aset pajak tangguhan, dan liabilitas pajak tangguhan secara simultan berpengaruh terhadap manajemen laba, maka hipotesis terbukti dan diterima.

Untuk peneliti selanjutnya diharapkan dapat menambah periode penelitiannya serta memperluas sektor perusahaan untuk sampel yang akan diteliti, hal ini dilakukan untuk menemukan hasil yang lebih valid, generalisasi hasil penelitian semakin baik dan meningkatkan daya uji empiris. Pengukuran lain dari manajemn laba dengan menggunakan proxy lainnya dapat dipertimbangkan.

\section{DAFTAR PUSTAKA}

Amanda, F., \& Febrianti, M. (2015). Analisis Pengaruh Beban Pajak Kini, Beban Pajak Tangguhan, dan Basis Akrual Terhadap Manajemen Laba, Ultima Accounting, 7 (01).

Anasta, L. (2015). Analisa Pengaruh Deferred Tax Asset, Deferred Tax Liabilities, dan Tingkat Hutang Terhadap Manajemen Laba Pada Perusahaan Sub Sektor Industri Makanan dan Minuman di Indonesia, Jurnal Tekun, 4 (02), 250-270.

Agoes, S., \& Trisnawati. (2010). Akuntansi perpajakan. 2 revisi ed. Jakarta: Salemba Empat.

Budiasih, I. (2011). Faktor Faktor yang Mempengaruhi Manajemen Laba, Jurnal Akuntansi, 1 (01), 10-22.

Casanova, B., \& Nindito, M. (2014). Pengaruh Aktiva Pajak Tangguhan dan Rasio Pahjak Terhadap Kinerja Laporan Keuangan Perusahaan Pada Perusahaan Yang Terdaftar di BEI, Jurnal Ilmiah Wahana Akuntansi, 9 (02).

Dhaliwal, D. S., Gleason, C. A., \& Mills, F. L. (2003). Last Chance Earnings Management: Using the Tax Expense to Meet Analysts' Forecasts, Contemporary Accounting Research, 21 (02), 2-32.

Febrianto, A. (2014). Pengaruh Beban Pajak Tangguhan dan Struktur Kepemilikan Terhadap Praktik Manajemen Laba Pada Perusahaan Manufaktur di BEI, Jurnal Tekun, 5 (02), 218229.

Ghozali, I. (2013). Aplikasi Analisis Multivariate dengan Program IBM SPSS 21. Semarang: Universitas Diponegoro.

Hani, S. (2007). Pengaruh Pajak Tangguhan Terhadap Beban Pajak Terutang PPH Badan, Jurnal Riset Akuntansi dan Bisnis, 7 (01).

Irreza, \& Yulianti. (2012). Penggunaan Komponen Pembentuk Pajak Tangguhan Dalam Mendeteksi Manajemn Laba, Jurnal Akuntansi dan Keuangan IndonesiaI, 9 (01), 68-82.

Junery, V. (2016). Pengaruh Beban Pajak Tangguhan, Bebean Pajak Kini dan Kompensasi Manajemen Terhadap Manajemen Laba, JOM Fekon, 13 (01).

Negara \& Suputra. (2017). Pengaruh Perencanaan Pajak dan Beban Pajak Tangguhan Terhadap Manajemen Laba, E-Jurnal Akuntansi Universitas Udayan, 20 (03), 2045-2072

Poterba, J.M., Rao, N. S., \& Seidman, J. K. (2011). Defered Tax Position and Incentives for Corporate Tax Changes, National Tax Journal, 64 (01), 27-58.

Purba, M. (2009). Akuntansi Pajak Penghasilan. Yogyakarta: Graha Ilmu.

Siswianingrum, N.P. (2016). Analisis Penerapan PSAK No.46 Terhadap Pajak Tangguhan PT.Merapi Production Surabaya, Jurnal Ilmu dan riset Akuntansi, 5 (08).

Sari, R.K., \& Zulaikha. (2015). Pengaruh Komponen Aset dan Kewajiban Pajak Tangguhan Terhadap Beban Pajak Kini Masa Depan, DiponegoroJournal Of Accounting, 4 (03),1-13.

Sözbilir, H., Kula, V., dan Baykut, L. E. (2015). A Research on Deferred Taxes: A Case Study of BIST Listed Banks in Turkey, European Journal of Business and Management, 7 (02).

Suranggane, Z. (2007). Analisis Aktiva Pajak Tangguhan dan Akrual Sebagai Prediktor Manajemen Laba, Jurnal Akuntansi dan Keuangan Indonesia, 4 (01), 77-94. 
Timuriana, T., dan Muhamad, R. R. (2015). Pengaruh Aset Pajak Tangguhan dan Beban Pajak Tangguhan Terhadap Manajemen Laba, Jurnal Ilmiah Akuntansi Fakultas Ekonomi, 1 (02), 12-20.

Widiariani, N. M. A., \& Sukartha, L. M. (2015). Pengaruh Aktiva Pajak Tangguhan dan Beban Pajak Kini Dalam Mendeteksi Income Maximization, E-Jurnal Akuntansi Universitas Udayana, 10 (03), 738-752. 